\title{
RESEARCH ON HO CHI MINH CITY CONGESTION PRICING BASEDON SPEED-DENSITY MODEL
}

\section{NGHIÊN CÚU PHÍ ÙN TẮC GIAO THÔNG TẠI THÀNH PHỐ HỔ CHÍ MINH DỰA TRÊN MÔ HİNH VẬN TỐC - MẬT Độ}

\author{
Nguyễn Anh Tuấn, Zhou Wen-Hui, Yu Jian-Jun \\ Trương Đại học Công Nghệ Hoa Nam - Khoa Quản Trị Kinh Doanh, Quảng Châu, Trung Quốc \\ (510640) - anhtuan_kts1706@yahoo.com
}

(Bài nhận ngày 21 tháng 07 năm 2014, hoàn chỉnh sửa chữa ngày 15 tháng 10 năm 2014)

\begin{abstract}
With the continuous growth of the urban population, traffic congestion has become a major problem in all cities. Congestion charging is in practice an effective tool to solve this problem. In this paper, we use the classical model of Congestion Charging to study the issues of pricingcharges in Ho Chi Minh City. In order to capture the traffic flow, we adopt the Drake speed - density model, which relies on the relationship of speed, density and flow and is further conducted by monitoring the traffic flow. After collecting the base traffic data of Ho Chi Minh City, we analyzed the relationship among speed, density and flow. The result showes that, the model we use performance better in reflecting the actual situation in Ho Chi Minh City than other models. Finally, this paper also numerically shows how much should charge to achieve the expected speed. The corresponding traffic density and flow are given in these examples as well.
\end{abstract}

Keywords: Traffic urban, Traffic congestion pricing, Speed - Density-flow relationships, Ho Chi Minh city.

\section{TÓM TẮT}

Với mật độ dân cu trong đô thị ngày càng gia tăng nhanh, ùn tắc giao thông đã trở thành vấn đề nghiêm trọng cho các thành phố lớn. Thu phí ùn tắc giao thông là môt công cu hiệu quả để giải quyết vấn đề này trong thưc tiễn. Trong báo cáo này, chúng tôi đã vận dụng mô hình cổ điển về định giá thu phí ùn tắc giao thông để nghiên cưu giải quyết giá thu phí tại Thành phố Hồ Chí Minh. Để xác định lưu luọng giao thông, chúng tôi áp dụng mô hình vận tốc - mật độ của Drake dưa vào mối quan hệ vận tốc mật độ - lư luợng và được tiến hành thêm bằng biện pháp giám sát luu luợng phuoong tiện giao thông. Sau khi thu thập dũ liệu một số tuyến đường giao thông của Thành phố Hồ Chí Minh, chúng tôi đã phân tích mối quan hệ giũa vận tốc - mật độ - luu luợng. Kết quả phân tích cho thấy, mô hình chúng tôi sủ dụng phản ánh tốt hơn tình hình thực tế tại Thành phố Hồ Chí Minh so với các mô hình khác. Cuối cùng, báo cáo không nhũng định lượng thể hiện được mức thu phí bao nhiêu để đạt đến vận tốc mong muốn. Tương ứng giá trị mật độ và lưu luọng giao thông được ước tính trong nhũng trường hợp này là tốt.

Tù khóa: Giao thông đô thị, Phí ùn tắc giao thông, Mối quan hệ vận tốc - mật độ - lưu luợng, Thành phố Hồ Chí Minh.

\footnotetext{
${ }^{1}$ Corresponding author. Email: yujj@ scut.edu.cn.

School of Business Administration, South China University of Technology, GuangZhou, China.

Acknowledgment: This project is supported by national natural science foundation of China (71271089, 71071059, 71301054), Guangdong province philosophy social science project (GD12CGL16), the fundamental research funds for the central universities (2013ZG0012, 2014X2D03).
} 


\section{INTRODUCTION}

With the rapid growth in population, the traffic congestion in large cities has become a big problem. Generally speaking, various traffic vehicles' traveling at the same peak hours contributes to the traffic congestion. Traffic congestion reduces the quality of citizens' life, restricts the economic development of the cities, and also affects the social stability, which has become one of the key factors limiting the all-round development of the cities. In order to solve this problem, many measures have been proposed, such as adding new routes and public vehicles and so on. Among these, traffic pricing has been regarded as a very effective method. The traffic charging scheme, which aims to easing traffic congestion, was first proposed in 1920s. In terms of its nature, the congestion pricing is to regulate people's habits of using transport vehicles. Specifically, congestion pricing is a kind of management measure using the price mechanism to control and regulate the traffic demands. It changes the traveler's selection of travel mode, travel route and time via collecting certain tolls from the vehicles travelling in and out of certain areas with congestion, so as to reduce the traffic flow in the areas with congestion, reduce unnecessary travel, and finally achieve the aim of easing the traffic congestion.

The concept of road congestion charging was first put forward by by the economist Pigou $^{[1]}$ in his publication of "welfare economics". In a simple network consisting of two paths, he proved that the speed of the vehicle on the road with tolls is higher than that without tolls, thus the congestion pricing brings efficiency. This traffic congestion pricing is different from the traditional road charges, because its purpose is to alleviate traffic congestion by means of controlling the traffic demands via charging the users, rather than to alleviate the fund shortage of road construction. The classic theory of marginal cost pricing indicates that the users' bearing cost is the average variable cost after joining in the traffic flow, namely the marginal personal cost (denoted as AC). However, the joining of a user will also increase the cost of other users in the whole traffic flow, which is called marginal social cost (denoted as MC). The users on crowded road must pay the fee which is equal to the difference between the marginal social cost and marginal personal cost, to offset the external non-economic effect of the whole system caused by his (her) travel. Pigou proposed the initial congestion pricing theory based on this theory. In this theory, the toll equals the difference between the marginal social cost and marginal personnel cost for any given traffic flow.

In practice, due to the difficulty to get the average speed of vehicles by observation, many scholars prefer to study the relationship between road density and the average speed of the vehicle. One of the optional methods which can find out the relationship between the traffic variables in large area is to use the road network simulation program. Such a microscopic traffic simulation was proposed by Williams etal. ${ }^{[2]}$. And the result in the large network turns out to be similar to than in a single road. In addition, many scholars use statistical method to capture the relationship between density and speed $^{[3]}$. In this paper, using the degree of fitting $R^{2}$ as the discriminant score $^{[4]}$, we select the most suitable speed-density model for the road in Ho Chi Minh City from several classic nonlinear model. Based on the selected model, we also give a simple inspection scheme to examine the effectiveness of traffic congestion pricing. 


\section{THE PRICIPAL OF ROAD CONGESTION PRICING}

In fact, the traveler has already paid a price for the crowed public road. Because this price is counted in time rather than in money, it is not very obvious for most travellers. As shown by Fougere et al. ${ }^{[5]}$, the commodity cost includes the cost and time of it. For example, even if it were a free lunch, we also need time to finish it. Similarly, if the public road were free, the user still needs to pay a cost for their travel time. Thus, if it takes the traveler a long time, his/her cost will outweigh the fun derived from the travel. In addition to the time cost, the traveler must also bear the increase in fuel costs and vehicle maintenance fee caused by the increasing time.

However, from the perspective of the rational allocation of road resources, congestion really creates social value. Considering that the congestion will greatly increase the cost of time-sensitive traveler, and slightly increase the cost of traveler who is not sensitive to the time and never care about waiting, the traveler who is sensitive to time will not take the travel, and the road shall be assigned to a really potential traveler who is not sensitive to the time. However, compared with the money, the time may be more precious, because the money can be earned back after using up, but the time is a thing that can not be obtained once it is gone.

Congestion leads to the very low utilization rate of the precious rsource (time). When considering whether to take the route, the traveler will generally make the decision depending on whether the expected earnings will be higher than expected costs, which includes time cost. The congested traffic will render more delay, and so increase the personal cost of the traveler. People always just consider their own personal costs of travel while making decisions. However, this will lead to higher social marginal cost, because the delay occurred not only on him, but also on the other travelers who are using the road at the same time.

Figure 1 shows the basic principle for the marginal cost pricing procedure to determine the charges. Consider a simple and standard situation where the uniform traffic flow can go forward along the road of uniform section with a given and fixed entrance and exit, and can also leave at any time. As is shown in figure 1, the $\mathrm{AC}$ curve represents the average congestion cost for any given demand, which the MC curve represents the marginal cost, namely the increasment of cost when there is a new vehicle joining in the traffic flow. MC can also be regarded as the social cost, because it can reflect the cost for all the users caused by this new joining vehicle. However, all the users make their decisions based only on their average cost, rather than on the social cost. Therefore, Yang and Huang ${ }^{[6]}$ think the difference between the MC curve and the $\mathrm{AC}$ curve under any given level of traffic flow reflectes the congestion cost in the traffic flow.

As we can see, the best demand (traffic flow) is the intersection of $Q_{a}$ between the marginal cost and demand curve. And when there is no congestion pricing, the user will ignore social costs, which leads to the best demand changing into $Q_{2}$. Therefore, the best congestion pricing shoud be $r_{0}$. In addition, because the demand function is often uncertain, $r_{0}$ cannot be determined easily. However, under the given congestion toll, the actual traffic flow can be observed. Hence, we can determin the optimal congestion toll by trial and error, i.e. setting a toll, observing the traffic flow and then modifying the toll. 
Figure 1: The pricing theory of the cost of traffic congestion

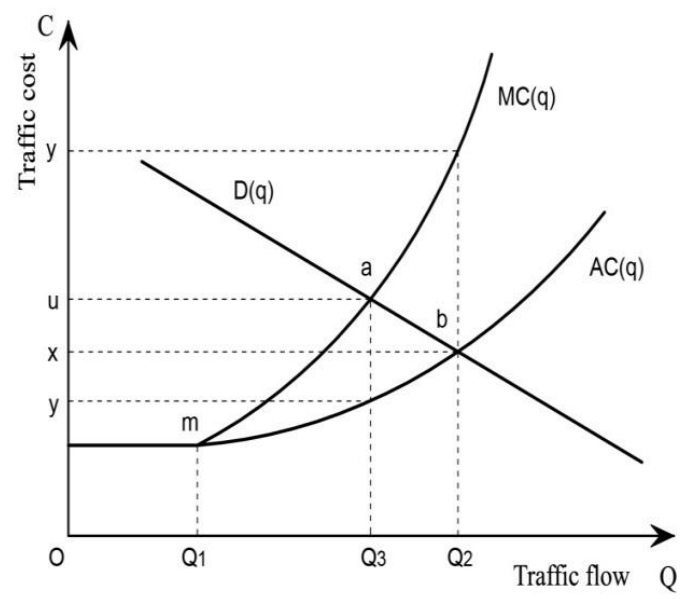

The classic pricing principle of marginal cost states that when a new user joins the congested road, he actually only bear the average variable cost. However, the join of this user will also increase the cost of other users in the whole traffic flow. Thus, the users who drive in crowded road must pay the charge equal to the difference between the marginal social cost and marginal personal cost, to offset the external non-economy of the whole system caused by their travel. As shown in figure 1, the curve of $\mathrm{D}(\mathrm{q})$ is the traffic demand line (user's willingness of using road under different costs), $\mathrm{C}$ is said the traffic cost, $\mathrm{y}$ and $\mathrm{u}$ are respectively said the travel marginal personal cost and marginal social cost when the traffic flow is $Q_{a}$, where $Q_{a}$ is said the traffic flow. Without any charge, the demand curve and the marginal personal cost line shall intersect, namely it shall be a balanced system when the traffic flow is $Q_{2}$. When using congestion toll, the demand curve shall intersect the marginal social cost at point a, namely it shall be a balanced system when the traffic flow is $Q_{\mathrm{a}}$. On this occasion, each user needs to bear the additional charge equals to $\mathrm{u}$ y.

\section{PRICING MODEL OF TRAFFIC CONGESTION}

According to the pricing theory based on marginal cost, the congestion toll should be set as the diofference between the marginal social cost and marginal personal cost, namely MC-AC. Let $\mathrm{D}$ be the distance of travel, $\mathrm{q}$ be the traffic flow, $\mathrm{V}$ be the average traffic speed, and $\mathrm{t}=\frac{\mathrm{D}}{\mathrm{V}}$ be the total travel time. Moreover, there is a relation between $\mathrm{V}$ and $\mathrm{q}$, namely $\mathrm{V}=$ $\mathrm{V}(\mathrm{q})$. Besides, denote $\mathrm{c}$ as the unit value of travel time of traveler, thus traveler's marginal personal cost $\quad A C(q)=c \times t=\frac{c D}{V(q)}$. For convenience, assuming that $\mathrm{D}=1 \mathrm{~km}$, so $\operatorname{AC}(q)=\frac{c}{V(q)}$. Furthermore, the social total cost (TC) is the sum of personal costs of all travelers, namely $\mathrm{TC}(\mathrm{q})=\mathrm{q} \times \mathrm{AC}(\mathrm{q})=\frac{\mathrm{cq}}{\mathrm{V}(\mathrm{q})}$. It can calculate the first derivative of the social total cost with respect to the flow q to obtain the marginal social cost, which is equivalent to $\operatorname{MC}(q)=\operatorname{TC}^{x} \times \operatorname{AC}(q)-\frac{c q V^{i}(q)}{\mathbb{V}^{2}(q)} . \quad$ Thus, the congestion toll (r) can be given as:

$$
\mathrm{r}=\mathrm{MC}(\mathrm{q})-\mathrm{AC}(\mathrm{q})=-\frac{\mathrm{cq} \mathrm{V}^{\prime}(\mathrm{q})}{\mathrm{V}^{2}(\mathrm{q})}
$$

On the relationship between the speed and flow, different scholars propose different models. According to the one of Drake, the congestion toll can be written as a function of the average speed of V:

$$
\mathrm{r}=\frac{\mathrm{e}}{\mathrm{V}} \mathrm{x} \frac{\operatorname{In}\left(\mathrm{e}^{\left.1 / \delta_{\mathrm{m}}\right)}-\ln V\right.}{\ln V-\ln V_{\mathrm{m}}}
$$

where $\mathrm{c}$ is the unit value of time for traveler (also known as value of time, VOT), $V_{\mathrm{f}}$ is the free-flow speed, $V_{\mathrm{m}}$ is the corresponding traffic speed under the maximum traffic flow, and $\delta$ is the parameter ready to be estimated. As the

Trang 132 
classical pricing model of congestion pricing, it has been applied to the practice in many countries, such as Singapore, Thailand, and so on. This paper will also use this model as a pricing strategy of traffic congestion pricing in the center of Ho Chi Minh City. However, because the model reflects the relationship between the congestion toll and average speed, it is necessary to measure the average speed while evaluating the effectiveness of the congestion toll, which will cost a lot of manpower and material resources. So, we shall design a simple test scheme to examine the effect of congestion toll based on the relationship among traffic speed, density and flow. At the same time, the parameters ( $\delta$ and $V_{m}$ ) in formula (2) shall also be captured by this relationship. Before this, we should firstly calculate the traveler's value of time c.

In General, there are two kinds of methods used to estimate travelers' unit value of time. The first is the "marginal wage method", and the second is "substitution ratio method". While using the "substitution ratio method", the value of travel time is usually regarded as the product of the amount of wage and a percentage. Wilson ${ }^{[7]}$ showed that the percentage was from $47 \%$ to $49 \%$. Recently, Png et al. ${ }^{[8]}$ found that the percentage should be $67 \%$. In this paper, two situations are considered: one is a conservative estimate with percentage $50 \%$, and the other is $67 \%$ as proposed by Png et al.

The above pricing strategy of congestion toll is calculated according to the average traffic speed, so it requires monitoring the average speed on the road while evaluating the effectiveness of the congestion toll ${ }^{[9]}$. However, it further requires people or devices to take record of the time and distance of each vehicle, so it will takes a lot of manpower, material resources and time. On the other hand, researches on the relationship between the road traffic, density and speed have been made by many scholars. This paper will give a test scheme of the effectiveness of congestion toll based on the findings in these researches. Monitoring the traffic flow is obviously much easier than monitoring the traffic speed, since monitoring the traffic flow only requires the record of total number of vehicles on the road in a certain period of time. In practice, this can be easily done by counting the numbers of vehicles in the entrance and exit of the road.

In practice, many scholars have studied the relationship among the flow q, the speed V and the road density $\mathrm{K}$ :

$$
\mathrm{K}=\frac{\mathrm{q}}{\mathrm{v}}
$$

With regard to the relationship of traffic density and speed, the most commonly used models are:

$$
\begin{aligned}
& \text { Green shield, } V=V_{\mathrm{f}}\left(1-\frac{\mathrm{K}}{\mathrm{K}_{\mathrm{m}}}\right) \\
& \text { Greenberg, } V=\mathrm{V}_{\mathrm{f}} \ln \left(\frac{\mathrm{K}}{\mathrm{K}_{\mathrm{m}}}\right) \\
& \text { Underwood, } \mathrm{V}=\mathrm{V}_{\mathrm{f}} \exp \left(\frac{-\mathrm{K}}{\mathrm{K}_{\mathrm{m}}}\right) \\
& \text { Drake, } V=\mathrm{V}_{\mathrm{f}} \exp \left[-\alpha\left(\frac{\mathrm{K}}{\mathrm{K}_{\mathrm{m}}}\right)^{5}\right]
\end{aligned}
$$

Among them, ${ }^{V_{\mathrm{f}}}$ is the free-flow speed, ${ }^{V_{\mathrm{m}}}$ is the traffic speed under the maximum flow, $\mathrm{Km}$ is the traffic density under the maximum flow, $\alpha$ and $\delta$ are the parameters to be estimated. It is not difficult to see that the Underwood model is a special case of Drake's model. Therefore, there is no need to study the Underwood model in this paper. In the next section, we respectively use the collected data to test these models, and then select the most $\mathrm{R}^{2}$ suitable one according to the degree of fitting $\mathbb{R}^{2}$. 


\section{TRAFFIC FLOW MEASUREMENT MODEL OF HO CHI MINH CITY}

In this section, we will compare the above four kinds of speed-density models (formula 4 , $5,6,7)$ to choose the suitable one as the traffic flow measurement and calculation model for Ho Chi Minh City. To this end, we measured the traffic flow as well as the corresponding speed and other data of the trunk roads and the downtown roads (especially in the area which will implement the traffic congestion toll) in October 2013 in Ho Chi Minh City, and get the influence of adopting traffic congestion charging policy by comparing the date before and after implementing the policy both in rush hours and not in rush hours ${ }^{[10]}$. For convenience and accurency, we first make an evaluation on the traffic management method within a certain range of area. Specifically, we made an investigation on the peripheral routes around the center of Ho Chi Minh City, where we set up 35 charging stations for data collection ${ }^{[1]}$. Since the congestion charging is mainly used to solve the traffic congestion problem happening in working days, we correspondingly only collected the data from two period of time in the rush hour of Ho Chi Minh City (7:00-9:00 and 16:00-19:00) in working days (from Monday to Friday). And, all the vehicles are divided into bicycle, motorcycle, car, vehicle for 12 to 15 people, buses, light trucks (below 2 tons), medium trucks ( 2 tons to 8 tons), heavy duty trucks and container, etc.

In order to facilitate the use of the traffic flow measurement and calculation model, we need to convert the different types of traffic vehicles into passenger vehicle equivalents ${ }^{[12]}$ (PCE). In this article, the passenger car equivalent is derived from the data collected in signal control intersection of a series of main road in the center of Ho Chi Minh City, and is given as follows:

Table 1: The PCE values of different Car Type

\begin{tabular}{|c|c|c|c|c|c|c|c|c|c|}
\hline $\begin{array}{c}\text { Type of } \\
\text { vehicles }\end{array}$ & bicycle & motorcycle & car & $\begin{array}{c}\text { vehicle } \\
\text { for 12 to } \\
15 \\
\text { people }\end{array}$ & Bus & $\begin{array}{c}\text { light } \\
\text { trucks } \\
\text { below 2 } \\
\text { tons) }\end{array}$ & $\begin{array}{c}\text { medium } \\
\text { trucks(2 } \\
\text { tons to 8 } \\
\text { tons) }\end{array}$ & $\begin{array}{c}\text { heavy } \\
\text { duty } \\
\text { trucks } \\
\text { (above 8 } \\
\text { tons) }\end{array}$ & container \\
\hline $\begin{array}{c}\text { Value } \\
\text { of PCE }\end{array}$ & 0.3 & 0.3 & 1 & 1.25 & 2.5 & 1.5 & 2.5 & 3.5 & 3.5 \\
\hline
\end{tabular}

Specifically speaking, a bicycle in the road can be converted into 0.3 passenger carequivalent, and a container truck can be converted 3.5 passenger car equivalent, and so on. The traffic department in Ho Chi Minh City monitored the traffic respectively from the rush hours of working days (from 6:00-9:00 and 16:00-19:00) in the center of studied area. In some lots, counting the number directly is feasible, so the direct statistical method is applied. In the lots with higher density of traffic flow, it is more difficult to use the direct statistical method, thus installing the camera system for indirect statistical method is necessary. According to the Vietnamese road traffic law, the highest speed of traffic vehicles in the center of the city should not be more than $40 \mathrm{~km} / \mathrm{h}$, namely the free speed is $40 \mathrm{~km} / \mathrm{h}$.

In the following, we will use the collected data to test the above speed-density models. To begin with, we should use formula (3) to calculate the road density (the maximum density $\mathrm{K}_{\mathrm{m}}$ is $251.47 \mathrm{PCE} \cdot \mathrm{h} / \mathrm{km}$ ). In order to 
use Excel to finish the remaining work, we need make the data transformation. Take Drake as an example, let $y=\ln \left(\frac{V_{f}}{V}\right), x=\frac{K}{K_{m}}$, formula (7) can be rewritten as:

$$
y=\alpha x^{8}
$$

Inputing the data into the Excel program, we have the following figure.

Figure 2: Regression analysis Drake's speed - density model

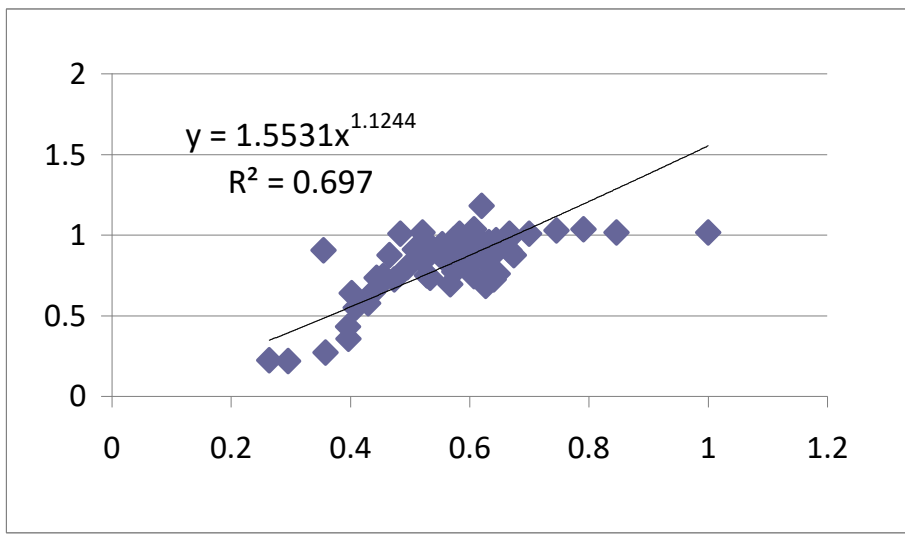

It can be seen that the $\mathrm{R}^{2}$ of Drake's model is 0.697 , the estimated parameters are $\alpha=1.5531$, and $\delta=1.1244$. Similarly, we use Excel to test the other models whose eastimated parameters and value of $R^{2}$ are shown in table 2 .

Table 2: Fitting compare several speed - density model

\begin{tabular}{|c|c|c|}
\hline Traffic flow model & \multicolumn{1}{|c|}{ Regression equation } & $\mathrm{R}^{2}$ \\
\hline Green shield & $\mathrm{V}=40\left(-0.577\left(1-\frac{\mathrm{K}}{151.47}\right)+0.771\right)$ & 0.471 \\
\hline Greenberg & $\mathrm{V}=40\left(-0.343 \ln \left(\frac{\mathrm{K}}{151.47}\right)+0.24\right)$ & 0.581 \\
\hline Drake & $\mathrm{V}=40 \exp \left(-1.5531\left(\frac{\mathrm{K}}{151.47}\right)^{1.1244}\right)$ & 0.697 \\
\hline
\end{tabular}

As we can see, Drake's model has a higher degree of fitting with the data of the center of Ho Chi Minh City, so this paper will use Drake's model as the basis for congestion pricing, namely

$$
V=40 \exp \left(-1.5531\left(\frac{K}{151.47}\right)^{1.1244}\right)
$$

Substituting $\mathrm{K}=$ into the above formula, we can get the relationship between the speed and flow:

$$
q=151.47 V(2.36-0.64 \ln V)^{0.889}
$$

According to the above formula, we can estimate the road current speed by detecting the traffic flow, and examine the effectiveness of congestion toll. 
By formula (2), we have " $=16.4 \mathrm{~km} / \mathrm{h}$. Therefore, the congestion toll is

$$
\mathrm{r}=\frac{\mathrm{c}}{\mathrm{V}} \mathrm{x} \frac{\ln 40-\ln V}{\ln V-\ln 16.4}
$$

\section{TRAFFIC CONGESTION CHARGING MODEL IN HO CHI MINH CITY}

In this paper, we first show how to calculate the unit value of travel time by using the "substitution ratio method". We assume that the month average income for the citizens in Ho Chi Minh City is 350 dollars. Moreover, they work 40 hours in average every week and work $52 / 12=4.33$ weeks each month. Thus, their monthly working time is $4.33 \times 40=173.2$ hours, and so $\mathrm{VOT}_{1}=350 / 173.2=2.02$ dollars.
Correspondingly, $\mathrm{c}_{1}=0.5=1.01$ dollars is the value of travel time conservative estimate with percentage $50 \%, \mathrm{c}_{2}=0.67 \mathrm{VOT}_{1}=1.35$ dollars is the value of travel time conservative estimate with percentage $67 \%$. Next, we calculate the unit value of travel time by using "marginal wage method". The average income of drivers owning their own private cars is said to be 500 dollars. Thus, the daily wage is $\mathrm{VOT}_{2}=$ $500 / 173.2=2.88$ dollars.

According to the above results by formula (9), it can be easily calculate the congestion toll for any specific speed, as well as its corresponding expected traffic flow and density, as shown in table 3 .

Table 3: Congestion costs are estimated

\begin{tabular}{|c|c|c|c|c|c|}
\hline \multirow{3}{*}{$\begin{array}{l}\operatorname{Speed}(\mathrm{V}) \\
(\mathrm{Km} / \mathrm{h})\end{array}$} & \multirow{3}{*}{$\begin{array}{c}\operatorname{Density}(\mathrm{K}) \\
(\mathrm{PCE} \cdot \mathrm{h} / \mathrm{km} / \text { lane })\end{array}$} & \multirow{3}{*}{$\begin{array}{l}\text { Flow }(q) \\
(P C E)\end{array}$} & \multicolumn{3}{|c|}{ Theoretical congestion charge (r) shouldspeed(V) } \\
\hline & & & \multicolumn{2}{|c|}{$\operatorname{voT}_{1}=2.02$ dollars } & \multirow{2}{*}{$\begin{array}{c}\mathrm{VOT}_{2}= \\
2.88 \\
\text { dollars }\end{array}$} \\
\hline & & & $c_{1}=0.5 \mathrm{VOT}_{1}=1.01$ dollars & $\begin{array}{c}c_{2}=0.67 \mathrm{VOT}_{1}=1.35 \\
\text { dollars }\end{array}$ & \\
\hline 17 & 89 & 1513 & 1.41 & 1.90 & 4.03 \\
\hline 18 & 83 & 1494 & 0.48 & 0.64 & 1.37 \\
\hline 19 & 78 & 1482 & 0.27 & 0.36 & 0.77 \\
\hline 20 & 73 & 1460 & 0.18 & 0.24 & 0.50 \\
\hline 21 & 69 & 1449 & 0.13 & 0.17 & 0.36 \\
\hline 22 & 64 & 1408 & 0.09 & 0.13 & 0.27 \\
\hline 23 & 60 & 1380 & 0.07 & 0.10 & 0.20 \\
\hline 24 & 56 & 1344 & 0.06 & 0.08 & 0.16 \\
\hline 25 & 52 & 1300 & 0.05 & 0.06 & 0.13 \\
\hline 26 & 48 & 1248 & 0.04 & 0.05 & 0.10 \\
\hline 27 & 44 & 1188 & 0.03 & 0.04 & 0.08 \\
\hline 28 & 41 & 1148 & 0.02 & 0.03 & 0.07 \\
\hline 29 & 37 & 1073 & 0.02 & 0.03 & 0.06 \\
\hline 30 & 34 & 1020 & 0.02 & 0.02 & 0.05 \\
\hline 31 & 30 & 930 & 0.01 & 0.02 & 0.04 \\
\hline 32 & 27 & 864 & 0.01 & 0.01 & 0.03 \\
\hline 33 & 23 & 759 & 0.01 & 0.01 & 0.02 \\
\hline 34 & 20 & 680 & 0.01 & 0.01 & 0.02 \\
\hline 35 & 17 & 595 & 0.01 & 0.01 & 0.01 \\
\hline 36 & 14 & 504 & 0.00 & 0.01 & 0.01 \\
\hline 37 & 10 & 370 & 0.00 & 0.00 & 0.01 \\
\hline 38 & 7 & 266 & 0.00 & 0.00 & 0.01 \\
\hline
\end{tabular}

\section{Trang 136}


Table 3 shows the traffic congestion toll and the corresponding expected speed when the unit values of travel time are 1.01 dollars, 1.35 dollars and 2.88 dollars respectively. Table 3 indicates that the higher unit value of travel time is, the higher congestion toll will be. Because the unit value of travel time determined by "marginal wage method" is calculated based on the average income of traveler, thus this method appears more accurent. Based on the selected model, the expected road speed is $17 \mathrm{~km} / \mathrm{h}$, which is not very different from the traffic speed under the maximum flow $V_{\mathrm{m}}=16.4 \mathrm{~km} / \mathrm{h}$, congestion toll are estimated is 4.03 dollars. Meanwhile, the expected road speed increases from $18 \mathrm{~km} / \mathrm{h}$ to $38 \mathrm{~km} / \mathrm{h}$, the corresponding congestion toll decreases from 1.37 dollars to 0.01 dollars. The formula (9) shows that the more the expected road speed increases compared with the traffic speed under the maximum flow $V_{\mathrm{m}}$, the more the corresponding congestion toll decreases. As we can see, when the expected road speed is 20 $\mathrm{km} / \mathrm{h}$, the congestion toll should be 0.5 dollars, and the expected density and traffic flow are respectively $73 \mathrm{PCE} \cdot \mathrm{h} / \mathrm{km} / \mathrm{lane}$ and $1460 \mathrm{PCE}$. Unlike the highway, because there is only one exit and entrance in the restricted area, the trip distance of vehicles that enter the restricted area can be determined. So we can directly calculate the total traffic congestion toll in this area, and conduct one-time charge when travelers enter the area. Based on the data of the traffic planning,

\section{REFERENCES}

[1]. Pigou A.C. The Economics of Welfare. MacMillan, London, (1920).

[2]. WilliamsJ.C, Mahmassani H.S,Herman R.Urban Traffic Network Flow Models. Transportation Research Record, Vol. 1112, No. 10,pp. 78-88, (1987). the length of the road of this restricted area is about $4.8 \mathrm{~km}$. Noting that the previously estimated traffic congestion toll in the paper is calculated on the basis of $1 \mathrm{~km}$ distance, therefore the price of traffic congestion toll in this restricted area is 2.4 dollars $(0.5$ dollars $/ \mathrm{km}$ multiplied by $4.8 \mathrm{~km}$ ).

\section{CONCLUSIONS}

The main contribution of this paper is to propose a simple scheme to examine the effectiveness of congestion toll. This scheme is based on the classic pricing model of congestion toll and the previous scholars' research on the relationship of speed-density-flow. The scheme only requires monitoring the number of vehicles on the road in a certain period of time, so this method is much more convenient than monitoring the average speed. However, this study does not consider the strategic behavior of controlling the vehicle in and out of the toll station, the location of the bus stop, and the behavior of disorderly parking of vehicles which has negative imoact on the traffic speed. At the same time, this study also does not in-depth study the phenomenon of speed adjustment due to the command of traffic signal system. In the future, we will comprehensively consider the impacts of these factors on the congestion pricing strategy, and design a simple examination plan accordingly.

[3]. Gou Guan-Ying, Zou Zhi-Jun. Algorithm of Vehicle Queuing Length Under Crowded Road. Department of Road and Traffic Engineering,Tongji University, Shanghai China Journal of Highway.Vol. 11, No. 3, pp. 92-95, (1998). 
[4]. Lum K, Fan H, Lam S, et al. Speed-Flow Modeling of Arterial Roads in Singapore. Journal of the Institution of Engineers. Vol. 124, No. 3,pp. 213-222, (1998).

[5]. Fougere M, Harvey S, Mercenier J, et al. Population ageing, time allocation and human capital: A general equilibrium analysis for Canada. Economic Modelling. Vol. 26, No. 1, pp. 30-39, (2009).

[6]. Yang H, Huang H.J. Principle of marginalcost pricing: how does it work in a general road network? Transportation Research Part A: Policy and Practice. Vol. 32, No. 1, pp. 45-55, (1998).

[7]. Wilson P.W. Welfare effects of congestion pricing in Singapore. Transportation. Vol. 15, No. 3, pp. 191-210, (1988).

[8]. Png G.H, Olszewski P, Menon A.P.G.Estimation of the value of travel time of motorists. Journal of the Institution of Engineers. Vol. 34, No. 2, pp. 9-13, (1994).

[9]. Drake J.S, Schofer J.L, May A.D. A statistical analysis of density hypotheses. Highway Transportation Research, (1967).

[10]. Japan International Cooperation Agency. Study on Urban Transport Master Plan and Feasibility: Study in Ho Chi Minh Metropolitan Area (Houtrans). Prepared by ALMEC Consultants, Japan, (2004).

[11]. Công ty Cổ phần Công Nghệ Tiên Phong. Nghiên cứu khả thi dự án: Thu phí xe ô tô luu thông vào Trung tâm Thành phố để hạn chế ùn tắc giao thông - (HCCS). Sở Giao thông Vận tải Thành phố Hồ Chí Minh, (2011).

[12]. TCVN 4054: 1998. Tiêu chuẩn thiết kế đuoòng Việt Nam. Việt Nam, (1998). 
